\title{
Performance and Feed Bio Economics of Growing West African Dwarf Goats Fed Diets Containing Graded Levels of Steam-Treated Cashew Nut Shell
}

\author{
Ocheja Josiah Omachi ${ }^{1}$, Usman Grace Ojali ${ }^{2}$, Ahmed Sule Hassanatu ${ }^{3}$, Boyi Prince Ufedojo ${ }^{4}$, \\ Akoh Josiah Omale ${ }^{4}$, Adamu Abdulmajid Tsobaza ${ }^{4}$, Eboh Sule ${ }^{5}$ \\ ${ }^{1}$ Department of Animal Science, Federal University, Kashere, Nigeria \\ ${ }^{2}$ Department of Food, Nutrition and Home Science, Kogi State University, Anyigba, Nigeria \\ ${ }^{3}$ Department of Animal Science, University of Benin, Benin, Nigeria \\ ${ }^{4}$ Department of Animal Production, Kogi State University, Anyigba, Nigeria \\ ${ }^{5}$ Department of Animal Science, University of Ibadan, Ibadan, Nigeria
}

Email address:

josiahocheja@yahoo.co.uk (O. J. Omachi)

\section{To cite this article:}

Ocheja Josiah Omachi, Usman Grace Ojali, Ahmed Sule Hassanatu, Boyi Prince Ufedojo, Akoh Josiah Omale, Adamu Abdulmajid Tsobaza, Eboh Sule. Performance and Feed Bio Economics of Growing West African Dwarf Goats Fed Diets Containing Graded Levels of SteamTreated Cashew Nut Shell. Animal and Veterinary Sciences. Special Issue: Promoting Animal and Veterinary Science Research. Vol. 8, No. 1, 2020, pp. 14-18. doi: 10.11648/j.avs.20200801.12

Received: October 1, 2019; Accepted: November 12, 2019; Published: January 31, 2020

\begin{abstract}
Studies on cashew (Anacardium occidentale) nut shell meal for feeding West African dwarf goats were carried out. Four diets containing $0 \%$ (control), $10 \%, 15 \%$ and $20 \%$ steam-treated cashew nut shell coded as $\mathrm{T}_{1}, \mathrm{~T}_{2}, \mathrm{~T}_{3}$ and $\mathrm{T}_{4}$, respectively, were compared. Twenty growing, West African dwarf goats were randomly assigned to four (4) treatments of five (5) goats each. The goats were fed and given water ad libitum. The effects of feeding graded levels of cashew nut shell based diets on performance and, Bio-economics were evaluated. Completely randomized design was used in the experiments. Data obtained were subjected to a one way Analysis of Variance (ANOVA) and means that were significantly different were separated using least significant difference (LSD) both contained in SPSS for window, version 16. Samples of the diets and bamboo leaves were analyzed using standard procedure. Final weight gain, total weight gain daily weight gain, $\left(5.0 \mathrm{~g}, \mathrm{~T}_{4}-13.00 \mathrm{~g}, \mathrm{~T}_{4} \mathrm{gW}^{0.75}\right)$ daily supplement intake $\left(44.65 \mathrm{~g}, \mathrm{~T}_{4}-91.54 \mathrm{~g}, \mathrm{~T}_{1}\right)$ and feed conversion ratio were significantly $(\mathrm{P}<0.05)$ different across the treatments. Values for initial weights and forage intake, were not significantly different $(\mathrm{P}>0.05)$. Cost of supplement reduced significantly $(P<0.05)$ from $T_{1}$ to $T_{4}$. Cost benefit ratio ranged from $0.79\left(T_{2}-1.63\left(T_{4}\right)\right.$ and showed significance differences. This study indicated that cashew nut shell could be fed to growing West African dwarf goats up to $10 \%$ level of inclusion without adverse effects on feed intake, growth performance, and feed conversion ratio. Diets containing graded levels of cashew nut shell could also provide a cheaper source of feed, and also help to reduce environmental pollution.
\end{abstract}

Keywords: Performance, Bio-economics, Feed Intake, West African Dwarf Goats, Cashew Nut Shell

\section{Introduction}

Majority of the ruminants in tropical Africa are raised on native pastures and crop residue [1]. During the dry season the natural pastures and crop residue available for ruminants after crop harvest are usually fibrous and devoid of most essential nutrients including protein, energy, minerals and vitamins which are required for increased rumen microbial fermentation and improved performance [2]. Most crop residues have generally been identified to have low nitrogen content; low intake and poor digestion. Supplementation with concentrate mixture including cereal bran and oil seed meal, have resulted in increased intakes in intensive production systems and have been the subject of several excellent reviews including that of Bangani [3]. Unfortunately, these supplements are often not fed due to their scarcity and their high cost [4]. The cost of conventional feed ingredients such 
as maize, soya beans etc has been on the increase from year to year, leading to increase in the price of animal protein. Also, the competition amongst man, animals and industry for some of these feed ingredients has further worsened the situation [5].

From the foregoing it is expedient therefore to expand the frontiers of feed resource for ruminants geared towards optimum performance, higher profits at lowered feed cost, with a view to reducing the cost of animal protein, thereby making it more affordable for Nigerians.

Cashew nutshell is a grossly underutilized agro by product which appear to be a promising feed resource for ruminant animals. This study was therefore designed to evaluate the potentials of cashew nut shell for feeding goats.

\section{Materials and Methods}

\subsection{Experimental Site and Housing Facilities}

The experiment was carried out at the Small Ruminants section of the Livestock Teaching and Research Farm of the Department of Animal Production, Kogi State University, Anyigba, which lies on Latitude $7^{\circ} 15^{\prime}$ and $7^{\circ} 29^{\prime} \mathrm{N}$ of the equator and Longitudes $7^{0} 11^{1}$ and $7^{0} 32^{1}$ East of the Greenwich Meridean, in the derived Savannah zone of Nigeria [6]. The annual rainfall is usually between $1400 \mathrm{~mm}-$ $1500 \mathrm{~mm}$ and lasts for about 6-7 months. The ambient temperature ranges from $25^{\circ} \mathrm{C}$ to $35^{\circ} \mathrm{C}$ with peaks in March and April [7].

\subsection{Experimental Feed Materials and Preparation}

The feed stuffs used were cashew nut shell, bamabara nut offal, maize offal, rice offal, fish offal meal, wood ash, bonemeal and table salt as well as bamboo leaves. The cashew nut shell (which was treated with steam for 20 minutes) was collected from the Cashew Kernel Processing Factory, Kogi State University, Anyigba. and there after pounded in a mortar using a pestle. All the feed components were mixed in different proportions and ground. The bamboo leaves were harvested from within Kogi State University, Campus, Anyigba.

Twenty (20) growing male West African dwarf goats weighing between $6.15 \mathrm{~kg}$ to $6.30 \mathrm{~kg}$ and aged between 7 and 9 months old were purchased from Anyigba and its environs. The animals were injected with Ivomec at $0.25 \mathrm{~mL} /$ goat to control both endo and ecto parasites. The goats were given prophylactic treatments by injecting them with antibiotics (Oxytetracycline hydrochloride and procaine penicillin) at 3 $\mathrm{mL}$ and $2 \mathrm{~mL}$ per goat) to take care of scouring, nasal and ocular discharges and to provide a common health status. The goats were ear-tagged to facilitate identification The experimental duration was 100 days, after an adjustment period of seven (7) days. Goats in treatments $T_{1}, T_{2}, T_{3}$, and $\mathrm{T}_{4}$ were fed with experimental diets containing $0,10,15$ and $20 \%$, cashew nut shell respectively at $100 \mathrm{~g} /$ goat/day. The Bamboo leaves were fed at $200 \mathrm{~g} / \mathrm{goat} / \mathrm{day}$ on cut and carry basis. All the goats were served water ad libitum. Daily feed intake (concentrate and bamboo), daily weight gain, Total weight gain and Feed conversion ratio were determined. Feed cost $/ \mathrm{kg}$, costs of feed consumed, benefit/ live weight gain and cost- benefit ratio were also determined. The bio economic indices were calculated using the method of Okolo et al [8]

\subsection{Chemical Analysis}

Samples of concentrate diets, steam- treated cashew nut shell and bamboo leaves (after drying in an oven) were prepared for analysis of their proximate composition and mineral content The protein content of the samples were analyzed using the Kjeldahl procedure. Ether extract, crude fibre and ash content were determined according to the method of AOAC [9]. The fibre composition of the concentrate diets, steam- treated cashew nut shell and bamboo leaves (Oxythenantera abyssinica) were further analyzed into, cellulose hemicellulose, lignin, Acid detergent fibre (ADF) and Neutral detergent fibre (NDF) according to the method of, Van Soest et al [10].

\subsection{Experimental Design and Statistical Analysis}

Completely randomized experimental design was used in designing the experiment. Data were subjected to a one-way analysis of variance (ANOVA) and treatment means were compared (separated) (where there were significant differences) applying the least significant difference (LSD) method. Using SPSS Statistical package for social science version 16.0 .

Table 1. Composition of Concentrate Diets (\% DM).

\begin{tabular}{lllll}
\hline \multirow{2}{*}{ Feed Components } & \multicolumn{4}{l}{ Composition/Treatments } \\
\cline { 2 - 5 } & $\mathbf{T}_{\mathbf{1}}$ & $\mathbf{T}_{\mathbf{2}}$ & $\mathbf{T}_{\mathbf{3}}$ & $\mathbf{T}_{\mathbf{4}}$ \\
\hline Cashew nut shell & 0.00 & 10.00 & 15.00 & 20.00 \\
Maize offal & 20.00 & 15.00 & 13.00 & 10.00 \\
Bambara nut offal & 52.00 & 52.00 & 52.00 & 52.00 \\
Fish offal meal & 5.00 & 5.00 & 5.00 & 5.00 \\
Rice offal & 18.00 & 13.0 & 10.00 & 8.00 \\
Wood ash & 2.00 & 2.00 & 2.00 & 2.00 \\
Table salt & 1.00 & 1.00 & 1.00 & 1.00 \\
Bone meal & 2.00 & 2.00 & 2.00 & 2.00 \\
Total & 100 & 100 & 100 & 100 \\
Calculated nutrient content (\% DM) & & & \\
Nutrients & & & & \\
Crude protein & 18.70 & 18.15 & 18.10 & 18.00 \\
Crude fibre & 16.31 & 16.32 & 16.46 & 16.83 \\
ME (Kcal/kgDM) & 3000 & 3050 & 3095 & 3132 \\
Calcium & 0.41 & 0.40 & 0.39 & 0.39 \\
Phosphorus & 1.19 & 1.19 & 1.18 & 1.18 \\
Magnesium & 0.78 & 0.77 & 0.77 & 0.77 \\
\hline
\end{tabular}

\section{Results and Discussion}

\subsection{Proximate Composition of the Concentrate Diets}

The proximate composition and fibre fractions of the concentrate diets are summarized in Table 2. The concentrate diet had similar protein and energy values across the 
treatments.

Protein content of about $18 \%$ was adequate for growing goats in the tropics and also above the critical protein requirement of $8 \%$ reported by Lakpini et al [11]. The ether extracts of $5.05 \%\left(\mathrm{~T}_{1}\right)$ was within the value recommended, however $8.75 \%\left(\mathrm{~T}_{2}\right)$ to $12.33\left(\mathrm{~T}_{4}\right)$ were above recommended values and may impede fibre digestion [12].

Table 2. Proximate Composition, Mineral and Fibre Fractions of the Concentrate Diets (\% DM).

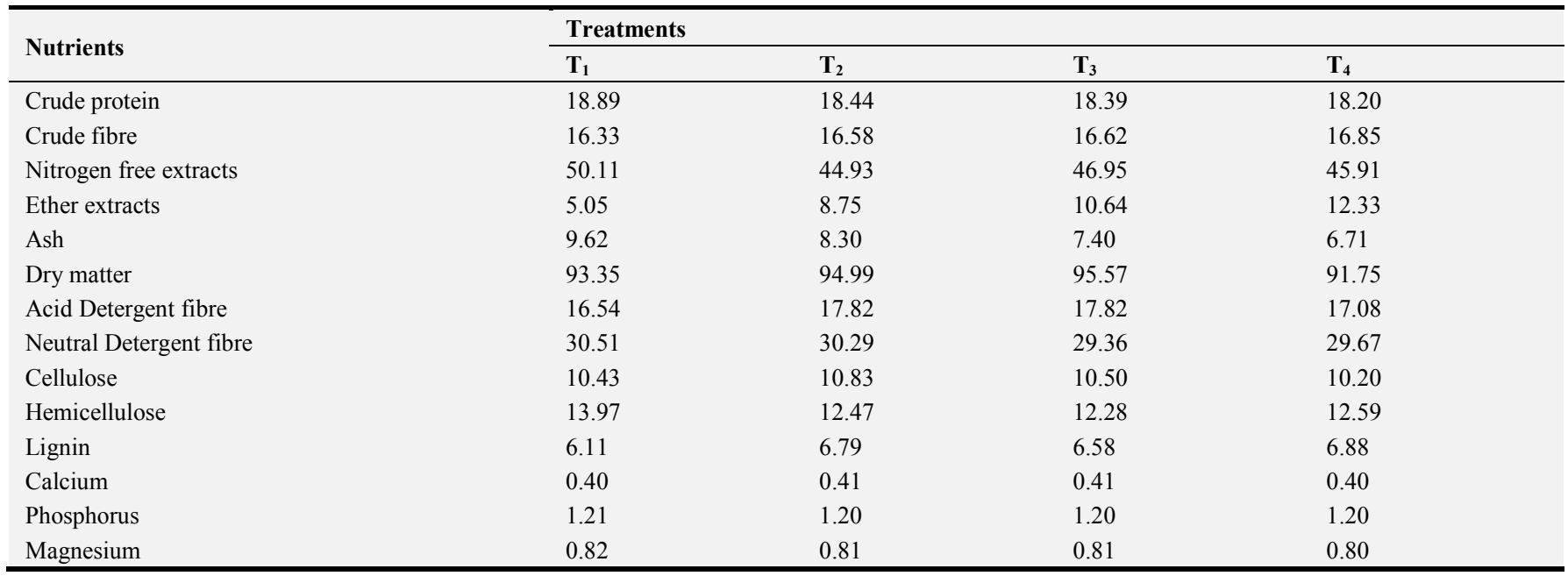

\subsection{Performance Data of Experimental Animals}

The performance data of growing West African dwarf goats fed diets containing graded levels of steam- treated cashew nut shell is summarized in Table 3. Initial weights of the animals as well as the daily forage intake were not significantly $(\mathrm{P}>0.05)$ different. Daily supplement intake decreased steadily from $91.54 \mathrm{~g} /$ day $\left(\mathrm{T}_{1}\right)$ to $44.65 \mathrm{~g} /$ day $\left(\mathrm{T}_{4}\right)$ and showed significant $(\mathrm{P}<0.05)$ difference across the treatment means. Final weight gain, total weight gain and daily weight gain decreased steadily from $\mathrm{T}_{1}(7.46 \mathrm{~kg}, 1.30$ $\mathrm{kg}$ and $13.0 \mathrm{~g}$ to $6.70 \mathrm{~kg}, 0.50 \mathrm{~kg}$ and $5.0 \mathrm{~g}$ respectively. Values for these three parameters showed significant $(\mathrm{P}<0.05)$ differences across the treatment means. The total daily feed intake ranged from $56.49\left(\mathrm{~T}_{4}\right)$ to $65.04 \mathrm{~g} / \mathrm{W}^{0.75}\left(\mathrm{~T}_{1}\right)$. Feed conversion ratio showed significant $(\mathrm{P}<0.05)$ difference with values for $\mathrm{T}_{1}$ and $\mathrm{T}_{2}$ being similar and significantly $(\mathrm{P}<$ ose of $\mathrm{T}_{3}$ and $\mathrm{T}_{4}$. Better feed conversion ratio of about 7.50 for red Sokoto goats fed cowpea husk supplemented with graded levels of Moringa oleifera leaves was reported by Mafindi et al [13].

The trend in daily supplement intake was due to inclusion of cashew nut shell in the diet in increasing order from $\mathrm{T}_{2}-$ $\mathrm{T}_{4}$, which led to a corresponding decrease in supplement intake. The mean daily weight gain range of $3.34\left(\mathrm{~T}_{4}\right)$ to 6.85
$\mathrm{gW}^{0.75}\left(\mathrm{~T}_{1}\right)$ where lower than $3.45-10.58 \mathrm{gW}^{0.75}$ reported for yearling West African Dwarf Goats fed sweet orange peel based diet, and $5.54-28.57 \mathrm{~g} /$ day for West African dwarf goat fed panicum maximum supplemented with Gmelina arborea leaves mixture reported by Ngi [14] and Adelusi et al [15]. This difference may be due to the class of goats as well as the feeds used in the experiments. The values recorded for total daily feed intake $56.49\left(\mathrm{~T}_{4}\right)$ to 65.04 $\mathrm{g} / \mathrm{day} / \mathrm{W}^{0.75}\left(\mathrm{~T}_{1}\right)$ were lower than $109.69-112.99 \mathrm{~g} / \mathrm{day} / \mathrm{W}^{0.75}$ reported when sweet orange peel meal based diets was fed to yearling West African dwarf goats by Oloche et al [16] The values were however $\mathrm{t}$ higher than $130.74 \mathrm{~g}$ to $210.37 \mathrm{~g}$ reported for West African Dwarf goats fed. Cassava leaf hay [17]. These differences may be due to the breed/class of goats used as well as the feeds involved in the experiments. The lower supplement intake and lower daily weight gain $(\mathrm{P}<0.05)$ in $\mathrm{T}_{3}$ and $\mathrm{T}_{4}$ may be due to the higher level of cashew nut shell in the diets. The cashew nut shell may have had an unpleasant taste. This again translated to lower total and daily feed intake. This may also have resulted in the lower weight gain reported in $T_{3}$ and $T_{4} . T_{1}$ and $T_{2}$ had the best feed conversion ratio. This could be that they best utilized the experimental diets. The trend in the feed conversion ratio was similar to that reported by Okolo et al [8].

Table 3. Feed intake and Weight gain of Growing West African Dwarf Goats Fed Bamboo leaf and supplementary Diets Containing Graded Levels of SteamTreated Cashew Nut Shell.

\begin{tabular}{|c|c|c|c|c|c|}
\hline \multirow{2}{*}{ Parameters } & \multicolumn{4}{|l|}{ Treatments } & \multirow{2}{*}{ SEM } \\
\hline & $\mathrm{T}_{1}(0 \% \mathrm{CNS})$ & $\mathrm{T}_{2}(10 \% \mathrm{CNS})$ & $\mathrm{T}_{3}(15 \% \mathrm{CNS})$ & $\mathrm{T}_{4}(20 \% \mathrm{CNS})$ & \\
\hline Numbers of observations & 5 & 5 & 5 & 5 & - \\
\hline Duration (days) & 100 & 100 & 100 & 100 & - \\
\hline Initial weight $(\mathrm{kg})$ & 6.16 & 6.20 & 6.27 & 6.20 & $\overline{0.14}$ \\
\hline Final weight $(\mathrm{kg})$ & $7.46^{\mathrm{a}}$ & $7.48^{\mathrm{a}}$ & $6.87^{\mathrm{ab}}$ & $6.70^{\mathrm{b}}$ & 0.15 \\
\hline Total weight gain $(\mathrm{kg})$ & $1.30^{\mathrm{a}}$ & $1.28^{\mathrm{a}}$ & $0.60^{\mathrm{b}}$ & $0.50^{\mathrm{c}}$ & 0.04 \\
\hline
\end{tabular}




\begin{tabular}{llllll}
\hline \multirow{2}{*}{ Parameters } & Treatments & & & \\
\cline { 2 - 6 } & $\mathbf{T}_{\mathbf{1}}(\mathbf{0 \%} \mathbf{C N S})$ & $\mathbf{T}_{\mathbf{2}} \mathbf{( 1 0 \% \mathbf { C N S } )}$ & $\left.\mathbf{T}_{\mathbf{3}} \mathbf{( 1 5 \%} \mathbf{C N S}\right)$ & $\left.\mathbf{T}_{\mathbf{4}} \mathbf{( 2 0 \%} \mathbf{C N S}\right)$ \\
\hline Total weight gain $\left(\mathrm{Wkg}^{0.75}\right)$ & $1.22^{\mathrm{a}}$ & $1.20^{\mathrm{a}}$ & $0.73^{\mathrm{b}}$ & $0.59^{\mathrm{c}}$ & 0.06 \\
Daily weight gain $(\mathrm{g})$ & $13.00^{\mathrm{a}}$ & $12.80^{\mathrm{a}}$ & $6.00^{\mathrm{b}}$ & $5.00^{\mathrm{c}}$ & 0.14 \\
Daily weight gain $\left(\mathrm{gW}^{0.75}\right)$ & $6.85^{\mathrm{a}}$ & $6.77^{\mathrm{a}}$ & $3.83^{\mathrm{b}}$ & 3.34 & 0.11 \\
Daily supplement intake $(\mathrm{g})$ & $91.54^{\mathrm{a}}$ & $85.65^{\mathrm{a}}$ & $67.37^{\mathrm{b}}$ & $44.65^{\mathrm{c}}$ & 7.62 \\
Daily supplement intake $\left(\mathrm{gW}^{0.75}\right)$ & $29.59^{\mathrm{a}}$ & $28.15^{\mathrm{a}}$ & $23.51^{\mathrm{b}}$ & $17.27^{\mathrm{c}}$ & 2.41 \\
Daily forage intake $(\mathrm{g})$ & 170.07 & 173.34 & 176.10 & 172.10 & 1.67 \\
Daily forage intake $\left(\mathrm{gW}^{0.75}\right)$ & 46.05 & 47.77 & 48.34 & 47.51 & 0.89 \\
Total daily feed intake $(\mathrm{g})$ & $261.61^{\mathrm{a}}$ & $258.99^{\mathrm{a}}$ & $243.47^{\mathrm{b}}$ & $216.75^{\mathrm{c}}$ & 2.96 \\
Total daily feed intake $\left(\mathrm{gW}^{0.75}\right)$ & $65.04^{\mathrm{a}}$ & $64.56^{\mathrm{a}}$ & $61.64^{\mathrm{b}}$ & $56.49^{\mathrm{c}}$ & 2.43 \\
Feed conversion ratio & $20.12^{\mathrm{a}}$ & $20.23^{\mathrm{a}}$ & $40.58^{\mathrm{b}}$ & $43.35^{\mathrm{b}}$ & 9.37 \\
\hline
\end{tabular}

$\mathrm{a}, \mathrm{b}, \mathrm{c}$, means on the same row with different superscripts differ significantly $(\mathrm{P}<0.05)$.

$\mathrm{SEM}=$ Standard Error of the Means.

\subsection{Feed Bio Economics of Growing West Africa Dwarf Goats}

The bio economics data of growing West African dwarf goats fed diets containing graded levels of steam-treated cashew nut shell is presented in Table 4. Cost of forage and cost of forage consumed did not show significant $(\mathrm{P}>0.05)$ difference across the treatments, cost of supplement $/ \mathrm{kg}$ decreased, steadily from $T_{1}(39.90)$ to $T_{4}(\# 30.40)$ and showed significant $(\mathrm{P}<0.05)$ difference Actual cost of total feed intake and benefit/live weight gain decreased steadily from $\mathrm{T}_{1}$ ( $\$ 875.30$ and $\$ 1040$ - $\$ 651.74$ and $\$ 400$ ) and showed significant $(\mathrm{P}<0.05)$ differences. Cost benefit ratio ranged from $0.84\left(\mathrm{~T}_{1}\right),-1.63\left(\mathrm{~T}_{4}\right)$ with $\mathrm{T}_{2}$ having the best, the values were significantly $(\mathrm{P}<0.05)$ different across the treatments.
The significant reduction in cost of supplement per $\mathrm{kg}$ was due to increasing levels of cashew nut shell from $T_{2}$ to $T_{4}$. The trend in the results for actual cost of total feed intake, benefit/ life weight gain and cost-benefit ratio tallies with those obtained when growing West African dwarf goats were fed with diets containing graded levels of cashew nut shell at $0 \%, 10 \%, 20 \%$ and $30 \%$ levels of inclusion by Okolo et al [8] This result showed that the inclusion of cashew nut shell in supplement diets for goats had significant and positive influence on the cost parameters of goat feeding. A costbenefits ratio range of 1.180 (T3) -1.210 (T4), which showed that farmers can acquire more benefits and less cost from the use of sun-dried cashew pulp as feed stuff for livestock feed. Was reported by Okpanachi et al [18]

Table 4. Feed Bio Economics of Growing West African Dwarf Goats Fed Bamboo leaf and supplementary Diets Containing Graded Levels of Steam-Treated Cashew Nut Shell.

\begin{tabular}{|c|c|c|c|c|c|}
\hline \multirow{2}{*}{ Parameters } & \multicolumn{4}{|l|}{ Treatments } & \multirow{2}{*}{ SEM } \\
\hline & $\mathrm{T}_{1}(0 \% \mathrm{CNS})$ & $\mathrm{T}_{2}(10 \% \mathrm{CNS})$ & $\mathrm{T}_{3}(15 \% \mathrm{CNS})$ & $\mathrm{T}_{4}(20 \% \mathrm{CNS})$ & \\
\hline Cost of supplement/kg ( & $39.90^{\mathrm{a}}$ & $34.15^{\mathrm{b}}$ & $31.45^{\mathrm{c}}$ & $30.40^{\mathrm{c}}$ & 0.39 \\
\hline 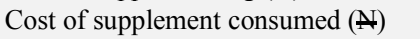 & $365.09^{\mathrm{a}}$ & $292.49^{\mathrm{b}}$ & $211.88^{\mathrm{c}}$ & $135.74^{\mathrm{d}}$ & 25.48 \\
\hline Cost of forage consumed ( & 510.21 & 520.02 & 528.30 & 516.00 & 7.41 \\
\hline *Actual cost of total feed intake ( & $875.30^{\mathrm{a}}$ & $812.51^{\mathrm{a}}$ & $740.18^{b}$ & $651.74^{\mathrm{c}}$ & 23.43 \\
\hline **Benefit/live weight gain $(\#)$ & $1040.00^{\mathrm{a}}$ & $1024.00^{\mathrm{a}}$ & $480.00^{b}$ & $400.00^{c}$ & 39.20 \\
\hline
\end{tabular}

a, b, c, d-Means on the same row with different superscripts differ significantly $(\mathrm{P}<0.05)$.

$\mathrm{SEM}=$ Standard Error of the Means.

* Cost of supplement intake plus cost of forage intake (on actual basis)

** Total weight gain $¥$ cost of a kg of Goat meat at $\$ 800$ (14)

*** Actual cost of total feed intake ( $) \div$ Benefit/ live weight gain.

\section{Conclusion and Recommendations}

\subsection{Conclusion}

Supplement diets containing graded levels of steam-treated cashew nut shell at $10 \%$, levels of inclusion fed to growing West African Dwarf Goats as supplement to Bamboo leaves, had no adverse effect on supplement intake, daily weight gain, feed conversion ratio, the $10 \%$ level of inclusion also produced the best cost parameters.

\subsection{Recommendations}

Steam-treated cashew nut shell included at $10 \%$ in concentrate diets for West African Dwarf Goat is recommended for optimum performance at reduced cost of feeding.

The use of cashew nut shell in ruminant rations could help reduce environmental pollution, since cashew nut shells that are dumped indiscriminately in cashew kernel processing areas can now be channeled into production of livestock feeds. 


\section{References}

[1] Tchinda, B., Wegad, D. and Njwe, R. W. (1993). Rumen degradation of Elephant grass supplemented with graded levels of perennial peanut by West African Dwarf Sheep. In: Labbie, S. H. B, Rey, B. and Irangu, E. K. (Editors) Small ruminants Research and Development in Africa Proceedings of the second Biannual Conference of the African Small Ruminant Research Network AICC Arusha, Tanzania 7 -11 December 1992 ILCA/CTA. ILCA Addis Ababa, Pp. 187-190 http:1/wwwfao.onz/wairoes!iLRIx5472B!'x5472b IIhtml.

[2] Onwuka, C. F. I, Akinsoyinu, A. O. and Tewe, O. O (1987). Feed value of some Nigerian browse species: Chemical composition and In-vtro digestibility of leaves. East African Agricultuer and forestry Journal, 54: 157-163.

[3] Bangani, N. M, Botha, J. A., Muller C. J. C. and Cruywagen, C. W. (2000). The production performance of lactating Jersey cows receiving varying levels of Lucerne hay and oat silage as roughage source. South African Journal of Animal Science, 3: 122-129.

[4] Nouala, F. S., Akinbamijo, O. O., Adewumi, A., Hoffman, E., Muetzeh, S. and Becker, K. (2006). The influence of Moringaoleifera leaves as substitute to conventional concentrate on the gas production and digestibility of groundnut hay. Livestock Research for Rural Development, 18 (9): 31-37.

[5] Adejinmi, O. O., Hamzat, R. A. and Fapohunda, J. B. (2007). Performance and nutrient digestibility of rabbits fed cocoa pod husk. Nigerian Journal of Animal production, 34 (1) 63-68.

[6] Ifatimehin, O. O, Musa, S. D and Adeyemi J. O (2009). An analysis of the changing land use and its impact on the environment of Anyigba town, Nigeria. Journal of sustainable Development in Africa, 10 (4): 22-29.

[7] Kowal, J. M. and Knabe, D. T. (1972). An Agroclimatological atlas of the Northern States of Nigeria Ahmadu Bello University Press Zaria. Pp. 23-25.

[8] Okolo, F. A., Ocheja J. O, Lalabe B. C. and Ejiga, P. A. (2012). Digestibility, performance and bio-economics of growing West African Dwarf Goats fed diets containing graded levels of cashew nut shell. International Journal of Agriculture and Rural Development, (IJARD), 15: 10001007.

[9] AOAC (1995) Association of Official Analytical Chemists.
Official methods of Analysis $16^{\text {th }}$ edition Washington, D. C. Pp. 1-20.

[10] Van Soest, P. J., Robertson, J. B. and Lewis, B. A. (1991). Methods of analysis for dietary neutral detergent fibre and non starch polysaccharides in relation to animal nutrition. Journal of Dairy Science, 74: 3583-3597.

[11] Lakpini, C. A. M., Adamu, A. M., Ehoche, O. W. and Gefu, J. O. (2002). Manual for Small Ruminant 8 Production in Nigeria. Compilation for a Training Workshop on Small Ruminant production held at the National Animal Production Research Institute, Zaria Nigeria $13^{\text {th }}-18^{\text {th }}$ January 2002 Pp. 55-62.

[12] Maithison, G. W., McAlhster, T. A., Cheng, K. J., Dong, Y., Galbraith, J. and Dmytruk, O. (1997). Methane emissions from farm animals. Abstract of workshop on green house Gas Research in Agriculture, Saint Foy March 12-14, Pp. 40-45.

[13] Mafindi U. M, Kiben A. U Zaklag D. U and Buda I. G (2018) Growth performance of red Sokoto goats fed cowpea husk supplemented with graded levels of Moringa oleifera leaves. Nigerian Journal of Animal Science. 20 (2) 173-182.

[14] Ngi, J. (2012). The nutritional potentials of sweet orange (Citrus sinensis) fruit peel meal for goat feeding. A Ph. D Thesis Submitted to the Department of Animal Production, University of Agriculture, Makurdi, Nigeria, $175 \mathrm{pp}$.

[15] Adelusi I A, Ajibike, A. B Muriana, T. O, Alalade J. A and Oladejo O (2016) Performance and Digestility of West African dwarf Goats fed panicum maximum supplemented with Gmelina arborea leave mixture. Nigerian Journal of Animal Science 18 (2): 518-524.

[16] Oloche, J., Oluremi, O. I. A. and Ayoade, J. A. (2013). Performance of West African Dwarf Goats fed diets containing graded levels of sweet orange (Citrus sinensis) peel meal. In: Akpa C. N., Dairo, F. A. S, Bawa, G. S, Solomon, I. P., Amaefule, K. N, Oduns,

[17] Arigbede, A. O., Adedeji, O. Y., Falola, O. O. and Saka, A. A. (2012). Performance characteristics and nutrient intake of West African Dwarf Goats fed cassava leaf hay- based diets. Proceeding $17^{\text {th }}$ Annual Conference of Animal Science Association of Nigeria, Abuja $9^{\text {th }}-13^{\text {th }}$ September, 2012 Pp. $559-562$.

[18] Okpanachi U, Ayoade J. A and Tuleun C. D (2016) Carcass characteristics, internal organs and economics of feeding sundried yellow cashew pulp based diets to west African Dwarf Goats. Animaland veterinary science 4 (3-1): 1-6 June 2016. 